\title{
Development of Software for Multiple Criteria Evaluation
}

\author{
Edmundas Kazimieras ZAVADSKAS, Leonas USTINOVICHIUS \\ Department of Construction Technology and Management \\ Vilnius Gediminas Technical University \\ Saulètekio al. 11, LT-2040 Vilnius, Lithuania \\ e-mail:edmundas.zavadskas@adm.vtu.lt
}

Friedel PELDSCHUS

Leipzig University of Applied Sciences

Karl-Liebknecht street 132, 04277 Leipzig

e-mail:peldschu@fbb.htwk-leipzig.de

Received: October 2002

\begin{abstract}
This paper considers the main positions of one-sided and two-sided problems. For onesided problems only the method of solution "the distance to the ideal point" is discussed in the actual version. For two-sided problems a distinction is made between games with rational behaviour and games against nature. The main strategic principles are as follows: simple min-max principle, extended min-max principle, Wald's rule, Savage criterion, Hurwicz's rule, Laplace's rule, Bayes's rule, Hodges-Lehmann rule. Questions of transforming the decision-making matrix are considered. The article gives the description of a software as well as an example of an investment variant estimation.
\end{abstract}

Key words: multiple criteria evaluation, one-sided problems, two-sided problems, game theory, linear transformation, non-linear transformation, estimation of investment efficiency.

\section{Introduction}

The problems of selection of rational construction variants are solved under various conditions, which are characterised by efficiency criteria (Sleiman and Hauglustaine, 2001; Zavadskas et al., 2001; Thiel and Mroz, 2001; Peldschus, 2001; Ustinovichius and Jakuchionis, 2000; Maliene, 2001). The criteria for each of the variants being compared (projects, strategies, alternatives) are calculated or set by means of experiments, upon assessing environmental conditions. These criteria are characterised by the information available. Decisions may be made under totally definite conditions (for a determined problem), upon evaluating one or several efficiency criteria. Now very much software is being developed and used for the multicriteria analysis. The main of them are:

- ELECTRE III software,

- ELECTRE IV software, 
- PREFCALC software,

- MAPPAC software,

- CARTESIA software,

- PROMCALC software.

The programs used: ELECTRE (Valee and Zielniewicz, 1994), UTA (JacquetLagreze, 1984; 1990), MAPPAC (Matarazzo, 1986; 1988; 1990), CARTESIA (Giarlotta, 1991), PROMETHEE (Brans et al., 1984; Brans et al., 1986) methods.

However, the cases are much more often, when decisions to be made are under the conditions of stochastic indefiniteness, i.e., indefiniteness occurring due to the influence of random factors, which are described by well-known objective laws. In such cases external actions are evaluated according to the distribution laws, which are determined by statistical methods. Decisions are often to be made even under total indefiniteness conditions. In such a case the laws determining effects of external actions are not known. Neither are known probabilities of effects of external actions. The decision is made by the way of comparison between merits and demerits of the possible variant under different environmental conditions.

An engineer or a technician tries to plan beforehand actions necessary to solve the problems. Machinery, devices and work methods are selected; their co-ordination is scheduled in space and time.

If we scrutinise the standard decisions relevant to construction technology and management, we shall become certain that deficiency of information is very often ignored. Experts make use of unfavourable initial data, their values applied are exaggerated, work is executed with poor quality models which, in case of need, are a bit corrected on the basis of practical experience, however reflect the actual situation insufficiently. Acting in such a way, experts make allowable decisions, but most often these decisions are unfavourable.

While researching into regularities, deficiency of information is attempted to evade. Application of regularities enables to evaluate results of necessary actions and to present the direction of their selection. Simple evaluation of all possible actions is not always sufficient. Each action may cause several sometimes contradicting each other results. As the actual result is not known, solutions criteria are necessary, which could take into consideration the totality of possible results. Various solution rules were proposed for optimisation in the presence of indefiniteness, on which basis the most favourable solution is selected out of a great number of possible solutions. Authors have been performing a research into the problem of multiple criteria evaluation for several years. All these calculations are fulfilled by LEVI 3.0 software (Peldschus et al., 2000; Zavadskas et al., 2002). The common aim has always been the evaluation of the optimal variant for production processes in the construction sector. Using this new software it is possible to find solutions for a task by means of different methods and to compare the solutions. 


\section{Structure and Methodology of the Development of Software}

Every problem to be solved is represented by a matrix, which contains variants (rows) and criteria (columns). The variants represent a set of situations for a problem that really exists. All variants considered are evaluated using the same criteria. The evaluation results are put in a matrix $a_{i j}, i=1, m ; j=1, n$.

Usually the criteria have different dimensions. That is why their effectiveness cannot be compared directly. An exception is the application of evaluation numbers without any dimensions according to a points system. This, however, involves subjective influences to a great extent. Hence, it should only be used in exceptional cases.

In order to avoid the difficulties due to different dimensions of the criteria, the ratio of the optimal value is used. In this way the discrepancy between different dimensions of optimal values is also eliminated. There are various theories about the ratio of the optimal value. Note that the decision for a theory may affect the solution. However, the values are mapped either on the interval $[0 ; 1]$ or on the interval $[0$, infinity) by the transformation.

Only those well-known theories of transformation are used that are appropriate for both problems of maximisation and minimisation.

Transformation through normalization of vectors is applied mainly to the method of solution "the distance to the ideal point" (Hwang et al., 1981), but may also be used for other methods (Zavadskas, 1991; Zavadskas et al., 1994). The ratio of the values remains constant for this transformation to the interval $[0 ; 1]$.

$$
b_{i j}=\frac{a_{i j}}{\sqrt{\sum_{i=1}^{m} a_{i j}^{2}}} .
$$

The linear transformation uses a scale of the existing values (Weitendorf, 1976). The calculated values are dependent on the size of the interval $\left[a_{i o} ; a_{i u}\right]$ and thus change if the interval is altered.

$$
\begin{aligned}
& b_{i j}=\frac{a_{i j}-a_{i u}}{a_{i o}-a_{i u}}, \text { if } b_{i j} \text { should be maximised, } \\
& b_{i j}=\frac{a_{i o}-a_{i j}}{a_{i o}-a_{i u}}, \text { if } b_{i j} \text { should be minimised, }
\end{aligned}
$$

where $a_{i o}$ is maximum value, $a_{i u}$ is minimum value.

The calculation of the relative deviation is a well performing linear transformation. The application of this transformation is limited to an interval $[0 ; 1]$.

Körth (1969) has offered the following formula for linear transformation:

$$
b_{i j}=1-\left|\frac{a_{j}^{*}-a_{i j}}{a_{j}^{*}}\right|,
$$

where $a_{j}^{*}$ is optimal value for the criterion. 
For linear transformation also it is possible to use Jüttler's (1966) method:

$$
b_{i j}=\frac{\left|a_{j}^{*}-a_{i j}\right|}{a_{j}^{*}},
$$

or Stopp's (1975) method:

$$
a_{i k}= \begin{cases}\frac{100 a_{i j}}{\max _{i} a_{i j}}, & \text { if } \max _{i} a_{i j} \text { is desirable, } \\ \frac{100 \min _{i} a_{i j}}{a_{i j}}, & \text { if } \min _{i} a_{i j} \text { is desirable. }\end{cases}
$$

In order to apply matrix game theory for solving problems of construction technology, dimensionless values are necessary, answering the following requirements:

- they are to express the ratio to the optimal value;

- they are to be independent of the type of matrix;

- given the same percentage differences, they are to be the same for maximisation as well as for minimisation;

- optimum values may replace any matrix.

To satisfy the above listed requirements, we offer the formulas below.

Using the non-linear transformation the calculation of the results is not dependent on the interval size. The values, however, are diminished more than by using other methods (Peldschus, 1986).

$$
\begin{aligned}
& b_{i j}=\left(\frac{\operatorname{Min}_{i} a_{i j}}{a_{i j}}\right)^{3} \quad \text { if } \underset{i}{\operatorname{Min}} a_{i j} \text { is desirable } \\
& b_{i j}=\left(\frac{a_{i j}}{\operatorname{Max}_{i} a_{i j}}\right)^{2} \text { if } \operatorname{Max}_{i} a_{i j} \text { is desirable. }
\end{aligned}
$$

Table 1 shows values of the gaining function for separate methods. It appears that the majority of methods are equal till the $100 \%$ difference of the minimal value. Should the difference be more than $100 \%$, heavy losses are partially calculated or no values are separated. While calculating according to the formulas (2), values are found according to the width of variation, entering new values of ratio for each problem. Calculations according to the formulas (3) have equal discontinuities. Parameters characterising the ratio do not change, and the quantity of values appears to be appropriate. The discrepancy between values is diminished given the same percentage difference in the problems of maximisation and minimisation, which is present in the formulas (3) and (6). However, in general all values are diminished more. 
Table 1

Values of gaining functions

\begin{tabular}{|c|c|c|c|c|c|c|c|c|c|c|c|c|c|c|}
\hline \multirow{2}{*}{ Methods } & & \multirow{2}{*}{$\begin{array}{l}\text { Opti- } \\
\text { mum } \\
\text { value }\end{array}$} & \multicolumn{12}{|c|}{ Optimum value difference } \\
\hline & & & $10 \%$ & $20 \%$ & $30 \%$ & $40 \%$ & $50 \%$ & $60 \%$ & $70 \%$ & $80 \%$ & $90 \%$ & $100 \%$ & $150 \%$ & $200 \%$ \\
\hline \multirow{2}{*}{$\begin{array}{l}\text { Peldschus } \\
\text { form. (6) }\end{array}$} & Max & 1.00 & 0.81 & 0.64 & 0.49 & 0.36 & 0.25 & 0.16 & 0.09 & 0.04 & 0.01 & 0 & - & - \\
\hline & Min & 1.00 & 0.75 & 0.58 & 0.46 & 0.36 & 0.30 & 0.24 & 0.20 & 0.17 & 0.15 & 0.13 & 0.06 & 0.04 \\
\hline \multirow{2}{*}{$\begin{array}{l}\text { Stopp's } \\
\text { method (5) }\end{array}$} & Max & 1.00 & 90 & 80 & 70 & 60 & 50 & 40 & 30 & 20 & 10 & 0 & - & - \\
\hline & Min & 100 & 91 & 83 & 77 & 71 & 67 & 63 & 59 & 56 & 53 & 50 & 40 & 33 \\
\hline \multirow{2}{*}{$\begin{array}{l}\text { Veitendorf's } \\
\text { form. (2) }\end{array}$} & Max & 0 & -0.10 & -0.20 & -0.30 & -0.40 & -0.50 & -0.60 & -0.70 & -0.80 & -0.90 & -1.00 & - & - \\
\hline & Min & 0 & -0.05 & -0.10 & -0.15 & -0.20 & -0.25 & -0.30 & -0.35 & -0.40 & -0.45 & -0.50 & -0.75 & -1.00 \\
\hline \multirow{2}{*}{$\begin{array}{l}\text { Körth } \\
\text { form. (3) }\end{array}$} & Max & 1.00 & 0.90 & 0.80 & 0.70 & 0.60 & 0.50 & 0.40 & 0.30 & 0.20 & 0.10 & 0 & - & - \\
\hline & Min & 1.00 & 0.90 & 0.80 & 0.70 & 0.60 & 0.50 & 0.40 & 0.30 & 0.20 & 0.10 & 0 & -0.50 & -1.00 \\
\hline \multirow{2}{*}{$\begin{array}{l}\text { Jüttler‘s } \\
\text { method (4) }\end{array}$} & Max & 0 & -0.10 & -0.20 & -0.30 & -0.40 & -0.50 & -0.60 & -0.70 & -0.80 & -0.90 & -1.00 & - & - \\
\hline & Min & 0 & -0.10 & -0.20 & -0.30 & -0.40 & -0.50 & -0.60 & -0.70 & -0.80 & -0.90 & -1.00 & -1.50 & -2.00 \\
\hline
\end{tabular}

Owen (1982), given the finite interval, offers linear transformation. Hersch and Carmozza (1976) have ascertained by empirical research that diminishing the utility value function is not to be constant, utility value may be non-linear, e.g., a hyperbolic function.

The difficulty lies in impossibility to find any suitable for any purpose gradation. In case of finite area, mapping of interval $[0,1]$ is single-valued. This corresponds to maximisation requirements.

While minimising, this area is within the interval $[0 ; \infty]$. However, this fact is only of theoretical value. In practical cases the highest value, the end of the interval exists. Unfortunately, this highest value is not always known, therefore it is impossible to use.

The offer is formulated in formula (6), the highest value is rejected. It is possible to calculate elements of the gaining matrix without knowing their values. Approximately, an asymmetric solution is calculated for a symmetric matrix. The other merit is better revelation of favourable values in comparison with the remaining ones.

Application of fractional elements of a matrix for improving the conformity of maximisation and minimisation functions does not give advantage for solution. Comparative calculations showed (Peldschus and Zavadskas, 1997) that the solution depends only on the type of function, and application of integer-valued elements of a matrix seems justified.

The formula suggested answers the requirements of construction technology and management problems in a better way.

After the transformation it is possible to evaluate the criteria with factors $0<q_{j}<1$. The sum of the weighting factors for the different criteria should equal 1 , otherwise errors might occur in the solution. Only well-founded weighting factors should be used because these are always subjective and influence the solution. 


\section{Methods of Solution}

A distinction is made between one-sided and two-sided problems for the methods of solution.

The one-sided problems are solved using well-known methods of the selection of variants and the determination of an order of precedence.

Using the game theory, the two-sided question aims at finding the equilibrium as a result of the rational behaviour of two parties having opposite interests or at the equilibrium in a game against nature.

\subsection{One-Sided Problems}

For one-sided problems only the method of solution "the distance to the ideal point" is considered in the actual version (Hwang and Yoon, 1981). A completion is planned.

Using the method "distance to the ideal point" an order of precedence according to the deviation from the ideal variant is determined. The solutions consists of the following steps.

The input matrix is transformed according to formula (1). With these dimension less values the set $a^{+}$(ideal variant) and $a^{-}$(negatively ideal variant) are calculated.

$$
\begin{aligned}
& a^{+}=\left\{\left[\left(\max _{i} f_{i j} / j \in J\right),\left(\min _{i} f_{i j} / j \in J^{\prime}\right)\right] / i=\overline{1, m}\right\}=\left\{f_{1}^{+}, f_{2}^{+}, \ldots, f_{n}^{+}\right\}, \\
& a^{-}=\left\{\left[\left(\min _{i} f_{i j} / j \in J\right),\left(\max _{i} f_{i j} / j \in J^{\prime}\right)\right] / i=\overline{1, m}\right\}=\left\{f_{1}^{-}, f_{2}^{-}, \ldots, f_{n}^{-}\right\},
\end{aligned}
$$

where $J$ is the set of the problems of maximisation and $J^{\prime}$ is the set of the problems of minimisation.

With the distances $L^{+}$and $L^{-}$

$$
\begin{aligned}
& L_{i}^{+}=\sqrt{\sum_{j=1}^{n}\left(f_{i j}-f_{j}^{+}\right)^{2}}, \quad \forall i, \quad i=\overline{1, m}, \\
& L_{i}^{-}=\sqrt{\sum_{j=1}^{n}\left(f_{i j}-f_{j}^{-}\right)^{2}}, \quad \forall i, \quad i=\overline{1, m} .
\end{aligned}
$$

The relative proximity to the ideal variant is determined:

$$
K_{i}=\frac{L_{1}^{-}}{L_{i}^{+}+L_{i}^{-}}, \quad \forall i ; \quad i=\overline{1, m} .
$$

The calculated values $K(i)$ are in the interval $[0 ; 1]$ and can be ordered in a decreasing sequence, which is the wanted order of precedence.

The limits of the interval are obtained from:

$$
K_{i}= \begin{cases}1, & \text { if } a_{i}=a^{+} \\ 0, & \text { if } a_{i}=a^{-}\end{cases}
$$




\subsection{Two-Sided Problems}

For two-sided problems a distinction is made between games with rational behaviour and games against nature. Matrix games are finite games of two-person null-sums. They can be deducted from $n$-person games. According to Burger (1963) $n$-person game of standard form is determined as totality of $n$ non-empty sets $S_{i}(i=1, \ldots, n)$ of $n$ person strategies and $n$-person payment functions $A_{i}(i=1, \ldots, n)$ defined in the set $S_{1} \times S_{2} \times \ldots \times S_{n}$.

The set product $S_{1} \times S_{2} \times \ldots \times S_{n}$ is the set of all collections $\left(s_{1}, \ldots, s_{n}\right)$, where $s_{1} \in S_{1}, \ldots, s_{n} \in S_{n}$. This game is designated as $\Gamma=\left\{S_{1}, \ldots, S_{n} ; A_{1}, \ldots, A_{n}\right\}$. Strategic sets $S_{1}$ may be topological structures, e.g., sets of Euclidean space points. The aim of the game is determined later.

\section{Games with Rational Behaviour}

The solutions for problems with rational behaviour are found in the ideal case as a saddle point solution (simple min-max principle) or as a combination of strategies (extended min-max principle) (Manteufel et al., 1977).

\section{Simple min-max principle}

$$
\begin{aligned}
& \alpha=\max _{i} \min _{j} a_{i j}, \\
& \beta=\min _{j} \max _{i} a_{i j} .
\end{aligned}
$$

If $\alpha=\beta=\nu$, the solution with pure strategies is a saddle point (only one optimal strategy for each player) - trivial solution.

\section{Extended min-max principle}

Calculation of a point of equilibrium with mixed strategies (combination of strategies)

$$
\max _{i} \min _{j} A\left(s_{1}, s_{2}\right)=\min _{i} \max _{j} A\left(s_{1}, s_{2}\right)=A\left(s_{1}^{*}, s_{2}^{*}\right)=\nu .
$$

\section{Games Against Nature}

Wald's rule. This method searches for the best of the worse solutions (Wald, 1945). The decision-maker acts according to the worst situation occurring - pessimistic attitude.

$$
S_{1}^{*}=\left\{S_{1 i} / S_{1 i} \in S_{1} \cap \max _{i} \min _{j} a_{i j}\right\} .
$$

Savage criterion. The aim is the minimisation of the loss of appropriateness, which is the difference between the greatest and the achieved benefit (Savage, 1951).

$$
S_{1}^{*}=\left\{S_{1 i} / S_{1 i} \in S_{1} \cap \min _{i} \max _{j} c_{i j} \cap c_{i j}=\left(\max _{r} a_{r s}\right)-a_{r s}\right\},
$$


where $r=\overline{1, m} ; s=\overline{1, n}$.

Disadvantage of the method: the presence of non-optimal strategies affects the solution.

Hurwicz's rule. The optimal strategy is based on the best and the worst result (Hurwicz, 1951). These values, calculated from the row minimum and row maximum, are unified to a weighted average using optimism parameters:

$$
S_{1}^{*}=\left\{S_{1 i} / S_{1 i} \in S_{1} \cap \max _{i} h_{i} \cap h_{i}=\min _{i} a_{i j}+(1-\lambda) \max _{j} a_{i j} \cap 0 \leqslant \lambda \leqslant 1\right\} .
$$

The value $\lambda=1$ gives the most pessimistic solution (Wald's rule). For the value $\lambda=0$ only maximal values are considered, greatest risk.

Bernoulli-Laplace's rule. The solution (Bernoulli, 1738) is calculated under the condition that all probabilities for the strategies of the opponent are equal to

$$
S_{1}^{*}=\left\{S_{1 i} / S_{1 i} \in S_{1} \cap \max _{i}\left(1 / n \sum_{i=1}^{n} a_{i j}\right)\right\} .
$$

Bayes's rule. If the probabilities for the strategies of the opponent are given, the maximum for the expected value can be used (Arrow, 1949).

$$
S_{1}^{*}=\left\{S_{1 i} / S_{1 i} \cap \max _{i}\left(\sum_{j=1}^{n} q_{j} a_{i j}\right) \cap \sum_{j=1}^{n} q_{j}=1\right\} .
$$

Hodges-Lehmann rule. With this rule (Hodges, Lehmann, 1952) confidence in the knowledge of the probabilities of the strategies of the opponent can be expressed by the parameter $\lambda$ :

$$
S_{1}^{*}=\left\{S_{1 i} / S_{1 i} \in S_{1} \cap \max _{i}\left[\lambda \sum_{j=1}^{n} q_{j} a_{i j}+(1-\lambda) \min _{j} a_{i j}\right] \cap 0 \leqslant \lambda \leqslant 1\right\},
$$

where $\lambda=0$ (no confidence) gives the solution according to Wald's rule. $\lambda=1$ (great confidence) gives the solution according to Bayes's rule.

\section{Example of a Calculation}

To illustrate application of the described methods, we shall consider the task of investments in construction. The task of efficiency of financial investments in reconstruction or construction in a health resort Nida (Lithuania) was analyzed. The number of investment variants was limited by requirements for reserve area and conservation of architectural 
Table 2

Basic data for estimating the investments efficiency

\begin{tabular}{lcccc}
\hline Investment variants & $\begin{array}{c}\text { Duration of } \\
\text { project } \\
\text { implementation } \\
\text { (years) }\end{array}$ & $\begin{array}{c}\text { The cost price of } \\
\text { the project } \\
(\text { LTL) }\end{array}$ & $\begin{array}{c}\text { Selling price of } \\
\text { the project } \\
\text { (LTL)* }\end{array}$ & $\begin{array}{c}\text { Predicted profit } \\
\text { (LTL) }\end{array}$ \\
\hline $\begin{array}{l}\text { Apartments in the } \\
\text { town centre }\end{array}$ & 1.5 & 4335000 & 7200000 & 2415000 \\
\hline $\begin{array}{l}\text { Hotel with partial } \\
\text { maintenance }\end{array}$ & 8.5 & 5200000 & 6500000 & 4200000 \\
\hline $\begin{array}{l}\text { Apartments at the } \\
\text { seaside }\end{array}$ & 1.3 & 3400000 & 4800000 & 1780000 \\
\hline
\end{tabular}

* LTL - Lits of Lithuania

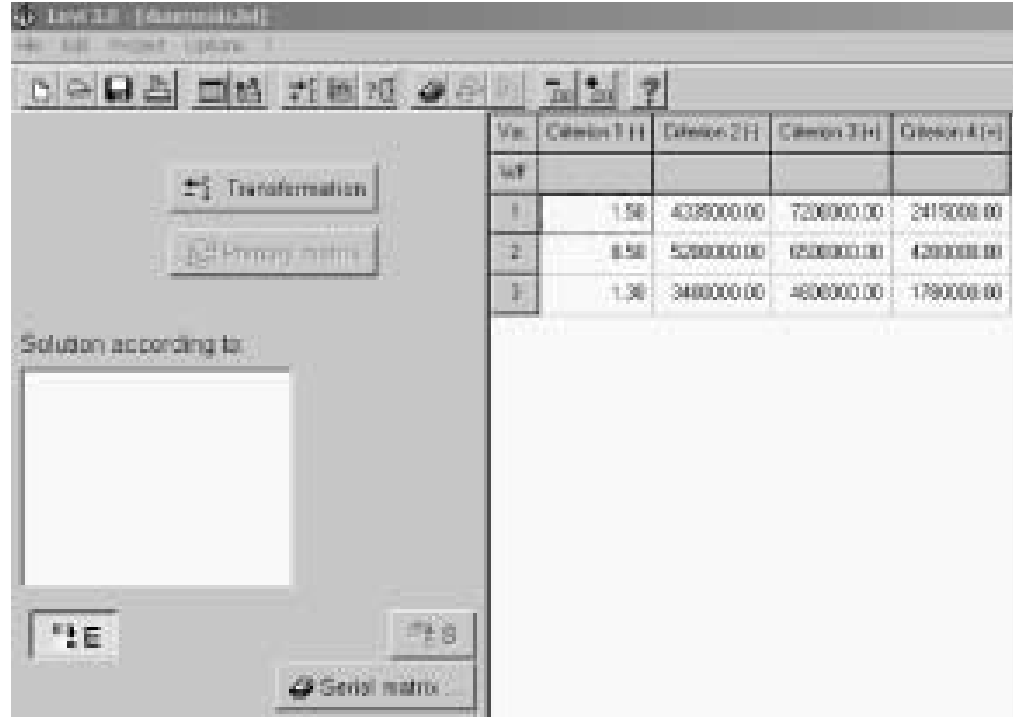

Fig. 1. Structure of data input.

monuments. Consequently, three investment variants were actually considered. It is possible to build a residential building or a hotel in the centre of the town, or a residential building at the seaside. Specific requirements for architecture in the centre of the town increase the construction cost. On the other hand, price of implementation of the project is higher in comparison with other urban areas. The hotel variant assumes partial maintenance, and further sale. Efficiency of the variant was evaluated by the following effectiveness indices: duration of project implementation, cost price of the project (site or building acquisition cost, cost of designing and erection and assembly work), selling price of the project, predicted profit. Bank interest rates were taken into account while calculating the amount of profit. Table 2, Fig. 1 provides the basic data. 


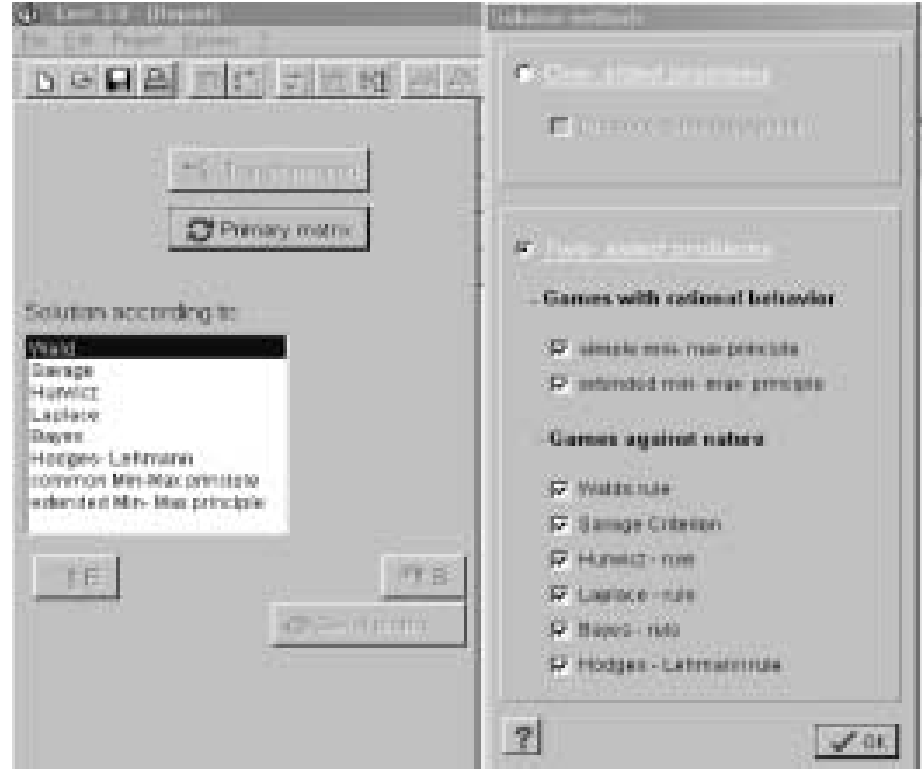

Fig. 2. Example of input of methods of a solution

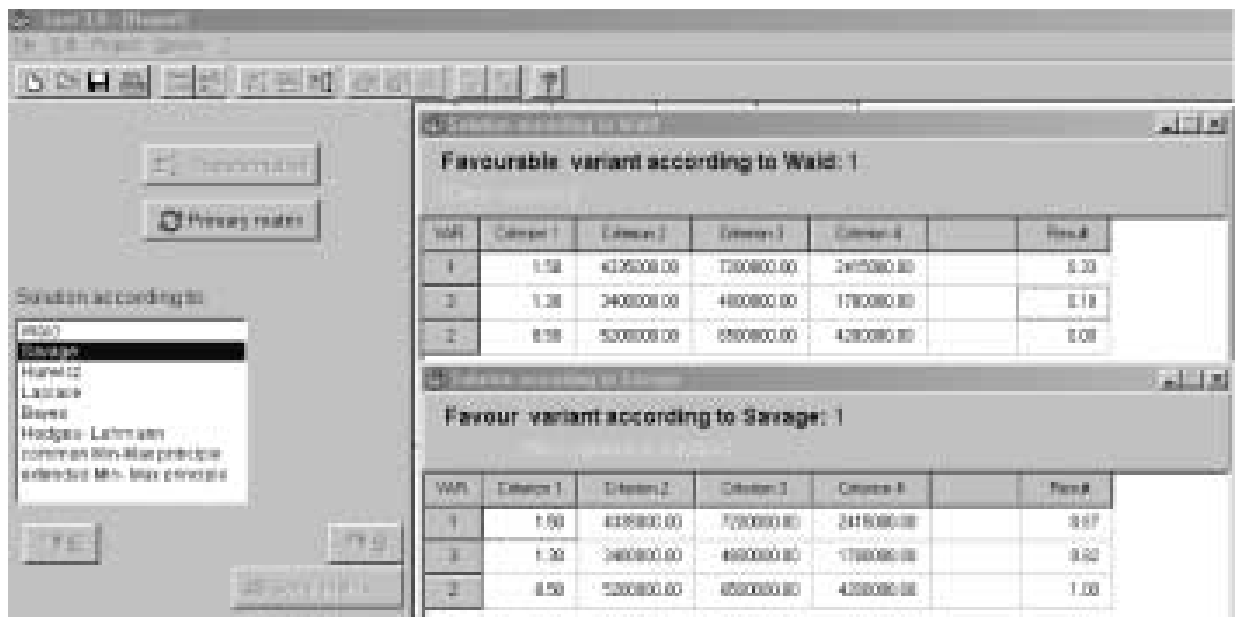

Fig. 3. Example of definition of best alternatives by Wald and by Savage.

Calculations were made applying criteria (Fig. 2) presented in 3.1 and 3.2. Table 3 provides the computation results. The definition example of the best alternatives by Wald and by Savage is presented in Fig. 3.

The first variant was considered as the most efficient on the grounds of the analysis of the results obtained. 
Table 3

Results of computation applying software LEVI 3.0

One-side problem, method of solution - "the distance to the ideal point"

\begin{tabular}{|c|c|c|c|c|c|c|c|}
\hline & & \multicolumn{2}{|c|}{ Variant 1} & \multicolumn{2}{|c|}{ Variant 2} & \multicolumn{2}{|c|}{ Variant 3} \\
\hline Values $K(i)$ & & \multicolumn{2}{|c|}{$0.698(1)$} & \multicolumn{2}{|c|}{$0.365(3)$} & \multicolumn{2}{|c|}{$0.623(2)$} \\
\hline \multicolumn{8}{|c|}{ Two-sided problem, linear transformation with use of the formula (2) } \\
\hline & $\begin{array}{l}\text { Wald's } \\
\text { rule }\end{array}$ & $\begin{array}{l}\text { Savage } \\
\text { criterion }\end{array}$ & $\begin{array}{l}\text { Hurwicz's } \\
\text { rule }\end{array}$ & $\begin{array}{l}\text { Laplace's } \\
\text { rule }\end{array}$ & $\begin{array}{c}\text { Bayes's } \\
\text { rule }\end{array}$ & $\begin{array}{c}\text { Hodges- } \\
\text { Lehmann } \\
\text { rule }\end{array}$ & $\begin{array}{l}\text { Min-max } \\
\text { principle }\end{array}$ \\
\hline Variant 1 & $0.26(1)$ & $0.74(1)$ & $0.262(1)$ & $0.679(1)$ & $0.679(1)$ & $0.602(1)$ & $17.14 \%(3)$ \\
\hline Variant 2 & 0 & 1 & 0 & $0.427(3)$ & $0.427(3)$ & & $43.31 \%(1)$ \\
\hline Variant 3 & 0 & 1 & 0 & $0.5(2)$ & $0.5(2)$ & & $39.56 \%(2)$ \\
\hline
\end{tabular}

Two-sided problem, non-linear transformation with use of the formula (6).

\begin{tabular}{cccccccc}
\hline & $\begin{array}{c}\text { Wald's } \\
\text { rule }\end{array}$ & $\begin{array}{c}\text { Savage } \\
\text { criterion }\end{array}$ & $\begin{array}{c}\text { Hurwicz's } \\
\text { rule }\end{array}$ & $\begin{array}{c}\text { Laplace's } \\
\text { rule }\end{array}$ & $\begin{array}{c}\text { Bayes's } \\
\text { rule }\end{array}$ & $\begin{array}{c}\text { Hodges- } \\
\text { Lehmann } \\
\text { rule }\end{array}$ & $\begin{array}{c}\text { Min-max } \\
\text { principle }\end{array}$ \\
\hline Variant 1 & $0.33(1)$ & $0.67(1)$ & $0.331(1)$ & $0.616(2)$ & $0.616(2)$ & $0.639(1)$ & \\
Variant 2 & $0.18(2)$ & $0.82(2)$ & $0.004(3)$ & $0.525(3)$ & $0.525(3)$ & & $45.15 \%(2)$ \\
Variant 3 & $0(3)$ & $1(3)$ & $0.18(2)$ & $0.656(1)$ & $0.656(1)$ & $54.85 \%(1)$ \\
\hline
\end{tabular}

Number of preferability of a variant is indicated in brackets.

\section{Conclusions}

The software LEVI 3.0 was developed for calculating the production processes in the building sector. Following the static equilibrium, the equilibrium in the game theory has a particular significance. Compared calculations with other methods of solution are necessary because the application of the equilibrium in the game theory to the building process is not always possible.

Apart from the practical use of the software LEVI 3.0, the scientific interest should be mentioned. Up to now it is not possible to evaluate the effects of the different methods of transformation on the numerical result. Another problem is the variety of the solutions. This causes difficulties for the practical user.

These problems are to be solved through the application of the software LEVI 3.0.

Use of the formula (6) improves the quality of transformation and allows to solve technological and organizational problems (tasks) more precisely.

\section{References}

Arrow, K.J. (1949). Bayes and minimax solutions of sequential decision problems. Econometrica, $213-243$. Bernouli, D. (1738). Specimen theoriae novas de mesure sortis. Comentarii Academiae Scientarium Inperialis Petropolitanae, 175-192. 
Brans, J.P., B. Mareschal and Ph. Vincke (1984). PROMETHEE - a new family outranking methods in multicriteria analysis. In J.P. Brans (Ed.), Operations Research '84, North-Holland. pp. 477-490.

Brans, J.P., Ph. Vincke and B. Mareschal (1986). How to select and how to rank projects: the PROMETHEE method. European Journal of Operational Research, 24, 228-238.

Burger, E. (1963). Introduction to the Theory of Games. Englewood Cliffs, Prentice-Hall.

Giarlotta, A. (1991). Multicriteria compensability analysis ranking totally the alternatives based on the employment of a non-symetric information axiom (CARTESIA). Annali dell Facolta di Economia e Commercio, 37, 1-33.

Hersh, H.M., and A.A. Carmozza (1976). Fuzzy set approach to modifiers and vagueness in natural language. Journal of Experimental Psychology, 105(3), 254-276.

Hodges Jr., J.L., and E.L. Lehmann (1952). The use of previous experience in reaching statistical decision. Annals of Mathematics Studies, 396-407.

Hurwicz, L. (1951). Optimality criteria for decision-making under ignorance. Cowles Commission Paper, Statistics, 370.

Hwang, C.-L., and K. Yoon (1981). Multiple Attribute Decision Making: Methods, Models and Applications. Springer-Verlag, Berlin.

Jacquet-Lagreze, E. (1984). PREFCALC: evaluation et decision multicritere. Revue de l'Utilisateur de l'IBM $P C, 3,38-55$.

Jacquet-Lagreze, E. (1990). Interactive assessment of preferences using holistic judgments: the PREFCALC system. In C. Bana e Costa (Ed.), Readings in Multiple Criteria Decision Aid, Springer-Verlag, Berlin, pp. $335-350$.

Jüttler, H. (1966). Untersuchungen zur Fragen der Operationsforschung und ihrer Anwendungsmöglichkeiten auf ökonomische Problemstellungen unter besonderer Berücksichtigung der Spieltheorie. Dissertation A an der Wirtschaftswissenschaftlichen Fakultät der Humboldt-Universität Berlin.

Körth, H. (1969). Zur Berücksichtigung mehrer Zielfunktionen bei der Optimierung von Produktionsplanen. Mathematik und Wirtschaft, 6, 184-201.

Maliene, V. (2001). Valuation of commercial premises using a multiple criteria decision-making method. Property Management, 5(2), 87-98.

Manteufel, K., and D. Stumpe (1977). Spieltheorie. Mathematik für Ingenieure, Naturwissenschaftler, Ökonomen und Landwirte, 21(1).

Matarazzo, B. (1986). Multicriterion analysis of preferences by means of pairwise actions and criterion comparisons (MAPPAC). Applied Mathematics and Computation, 18(2), 119-141.

Matarazzo, B. (1988). A more effective implementation of the MAPPAC and PRAGMA methods. Foundations of Control Engineering, 13, 155-173.

Matarazzo, B. (1990). A pairwise criterion comparison approach: the MAPPAC and PRAGMA methods. In C. Bana e Costa (Ed.), Readings in Multiple Criteria Decision Aid, Springer-Verlag, Berlin, pp. 253-273.

Owen, G. (1982). Game Theory. Second ed. Acad Press.

Peldschus, F. (1986). Zur Anwendung der Theorie der Spiele für Aufgaben der Bautechnologie. Dissertation B. TH Leipzig, $119 \mathrm{~S}$.

Peldschus, F. (2001). Sensibilitätsuntersuchungen zu Methoden der mehrkriteriellen Entscheidungen. Statyba (Journal of Civil Engineering and Management), VII(4), 276-280.

Peldschus, F., and E. Zavadskas (1997). Matrix Games in Building Technology and Management, Vilnius (in Lithuanian).

Peldschus, F., E.K. Zavadskas and L. Ustinovichius (2000). LEVI 3.0 - a program for multiple criteria evaluation. In $52^{\text {th }}$ Meeting of the European Working Group "Multicriteria Aids for Decisions", Vilnius. pp. 32 36.

Savage, L.J. (1951). The theory of statistical decision. Journal of the American Statistical Association, 55-57.

Sleiman, A., and J.M. Hauglustaine (2001). Multicriteria and multiple actors tools aiding to optimise building envelope at the architectural sketch design. Informatica, 12(1), 3-24.

Stopp, F. (1975). Variantenvergleich durch Matrixspiele. Wissenschaftliche Zeitschrift der Hochschule für Bauwesen Leipzig, Heft 2.

Thiel, T., and T. Mroz (2001). Application of multi-criterion decision aid method in designing heating systems for museum buildings. Informatica, 12(1), 147-168.

Ustinovichius, L., and S. Jakuchionis (2000). Multi- criteria analysis of the variants of the old town building renovation in the marketing. Statyba (Journal of Civil Engineering and Management), VI(6), 212-222. 
Valee, D., and P. Zielniewicz (1994). ELECTRE III and IV 3.x. Aspects methodologiques, LAMSADE, Document 85, Paris.

Wald, A. (1945). Statistical decisions functions which minimize the maximum risk. Annals of Mathematics, 265-280.

Weitendorf, D. (1976). Beitrag zur Optimierung der räumlichen Struktur eines Gebäudes. Dissertation A, Hochschule für Architektur und Bauwesen, Weimar.

Zavadskas, E. (1991). Systems of Estimation of Technological Solutions in Building Construction. Strojizdat, Leningrad (in Russian).

Zavadskas, E.K., A. Kaklauskas and N. Kvederytė (2001). Multivariant design and multiple criteria analysis of a building life cycle. Informatica, 12(1), 169-188.

Zavadskas, E., E. Peldschus and A. Kaklauskas (1994). Multiple Criteria Evaluation of Projects in Construction. Technika, Vilnius.

Zavadskas, E.K., L. Ustinovichius, Z. Turskis, F. Peldschus and D. Messing (2002). LEVI 3.0-Multiple criteria evaluation program for construction solutions. Journal of Civil Engineering and Management, 8(3), 184 191.

E.K. Zavadskas is a Dr habilius, professor, Dr honoris causa of Poznan University of Technology, vice rector of Vilnius Gediminas Technical University (Lithuania). Member of Lithuanian Academy of Sciences, president of Lithuanian Operational Research Society, president of Alliance of Experts of Projects and Buildings of Lithuania. He is editorin-chief of the journals: Journal of Civil Engineering and Management, Technological and Economic Development of Economy; editor of the journal Property Management. In $1973 \mathrm{PhD}$ degree in building structures. Assistent, senior assistent, associate professor, professor at the Department of Construction Technology and Management. In 1987, Dr habilius at Moscow Civil Engineering Institute (construction technology and management). Research visits to Moscow Civil Engineering Institute, Leipzig and Aachen Higher Technical Schools. He maintains close academic links with the universities of Aalborg (Denmark), Salford and Glamorgan (UK), Poznan University of Technology (Poland), Leipzig University of Applied Sciences (Germany). Member of international organisations. Member of organisational and programme committees of many international conferences. Member of editorial boards of some research journals. Author of monographs in Lithuanian, English, German and Russian. Research interests: building technology and management, decision-making theory, automation in design, expert systems.

L. Ustinovichius is PhD of technical sciences, associate professor, chairman of Laboratory of Construction Technology and Management, Vilnius Gediminas Technical University (Lithuania). Leonas Ustinovičius, together with prof. E.K. Zavadskas, works in scientific and practical field, important nowadays. That is authorised design of one-storey industrial buildings installation and multipurpose selectonovation in the construction of technological decisions. The essence of the trend is creation of the automated system, improvement of project quality. For this work in $1987 \mathrm{~L}$. Ustinovičius was awarded a bronze medal in the Exhibition of the Achievements in National Economy. Research interests: old town regeneration, multi-criteria analysis. He is the author of 70 scientific articles. 
F. Peldschus is a Dr habilius, professor, Dr honoris causa of Vilnius Gediminas Technical University, Department of Civil Engineering and Building Construction, Leipzig University of Applied Sciences. F. Peldschus studied building construction, welding and data processing at Leipzig Building School. He has defended the theses of Dr engine and Dr habilius techn., both of them deal with the application of the game theory to building technology problems. Author of 55 publications. Research interests: optimisation of planning, multicriteria solutions and building processes.

\section{Daugiakriterinio ivertinimo programu vystymas}

Edmundas Kazimieras ZAVADSKAS, Leonas USTINOVIČIUS, Friedel PELDSCHUS

Straipsnyje nagrinėjamos pagrindinès vienpusės ir dvipusės problemu nuostatos, sprendžiant sprendimų prièmimo uždavinius. Vienpusiams uždaviniams spręsti naudojamas idealaus taško metodas. Dvipusiu problemu sprendimui taikomi pusiausvyros strategijos minimakso principas, Wald, Savage, Hurwicz, Laplace, Bayes, Hodges-Lehmann taisyklès.

Optimizacijai neapibrěžtumo atveju buvo pritaikytos minètos sprendimo taisyklès, pagal kurias iš daugybès galimų sprendinių išrenkamas palankiausias. Šiuos skaičiavimus atlieka programa LEVI 3.0.

Daugiakriterinio įvertinimo programos panaudojimo galimybės parodomos sprendžiant statybos uždavini, nustatant investicijų efektyvumą. 